\title{
Achievements and Gaps in the Application of the Land Registration System in ANRS: The Case of West Gojjam Zone
}

\author{
Melkamu Belachew Moges*
}

\section{Abstract}

Land registration system has been put in place in the rural areas of Amhara National Regional State (ANRS) since 2002. The courts in the regional state decide on land disputes based on land information obtained from the land administration offices. These offices are expected to supply the information available at the land registration system. However, land administration and use offices often get the information directly from the public on an individual case basis following order from a court. This is mainly attributable to the low level of using the land registration system in the region by the land administration offices and legal professionals. The land registration system is not used to its maximum potential to alleviate the problem of land dispute. A case study approach is used in this article, and five rural woredas were purposively chosen because of high prevalence of land disputes. Questionnaires, focus group discussions (FGDs) and court cases are used. The research indicates the need for a strong institutional and regulatory mechanism of land management in ANRS.

\section{Key terms}

Land dispute $\cdot$ Land registration $\cdot$ ANRS - Land administration and use office $\cdot$ Ethiopia

DOI http://dx.doi.org/10.4314/mlr.v14i1.2

This article is licensed under a Creative Commons Attribution-

NonCommercial-NoDerivs (CC BY-NC-ND)

Received: 31 March 2020 (Version 2)

Accepted: 6 September 2020

\section{Suggested citation:}

Melkamu Belachew Moges (2020), 'Achievements and Gaps in the Application of the Land Registration System in ANRS: The Case of West Gojjam Zone', 14 Mizan Law Review 1:31-60

- Melkamu Belachew Moges, LLB (AAU), MSc (KTH), PhD in Law (UniMelb), LL.D. Hon. (Commonwealth Uni.), Graduate Certificate (UniMelb).

Email: melkgrowthf@gmail.com

This research is adapted from a previous research submitted to and funded by the Institute of Land Administration, Bahir Dar University, in 2011. I am grateful to Bahir Dar University for funding this research. 


\section{Introduction}

Land registration systems (also known as cadastral systems) play key role in reducing land disputes. ${ }^{1}$ They provide evidence of title to a landholder with respect to a particular land parcel and show the boundaries of land parcels. This in turn helps reduce land disputes by assisting the remedial measure after an act of violation of a land right. The frequency of boundary disputes is usually correlated to the quality of the cadastre or land information system including primarily its being up-to-date. For instance, a land registration system with full and clear information about land can be used to curb conflicts.

Following the reform that aimed at the introduction of modern land management system, Amhara region has introduced land registration system since 2002. First level land registration covered all administrative Zones immediately. West Gojjam Zone is one of the 15 administrative zones in Amhara region. One can easily observe problems in correctly applying the new land registration system in the courts of Amhara region when they attempt at settling land disputes. Resources are wasted, and the quality of court decisions are adversely affected. This article highlights the concept to land registration system and examines the challenges in land registration system in West Gojam Zone in relation with reducing or resolving land disputes.

Given the common use of land registration for tenure security, indicating the major bottlenecks in the application of the land registration system for land dispute resolution will trigger strengthened attempts at increasing the capacity and role of the system and its legitimacy for the users. The research has used a case study approach. Five rural woredas were chosen for the case study: Bahir Dar Zuria Woreda, Mecha Woreda, South Achefer Woreda, Yilmanadensa Woreda, and Bure Woreda.

The respondents of questionnaires include 23 land administration and use staff and 11 judges. Focus group discussions (FGDs) and court case analysis have also been made. Seven judges were selected from the Supreme Court of

\section{Acronyms:}

ANRS Amhara National Regional State

FDRE Federal Democratic Republic of Ethiopia

${ }^{1}$ Nazneen Kanji, et al (2005), Written Research Report 1: Can Land Registration Serve Poor and Marginalised Groups? Summary Report (The UK's Department for International Development), p. 22; Tim Hanstad (1998), 'Designing Land Registration Systems for Developing Countries', American University International Law Review, Vol. 13, Issue 3, p. 663. 
the Amhara National Regional State (ANRS) and four judges were from West Gojjam Zone High Court. Moreover, due attention is given to literature review and critical discussion of the legal system vis-a-vis the role of land registration in land dispute prevention and resolution. The empirical aspect of the case study is meant to give insights to comparable or similar problems in locations which share similar objective realities.

The article has seven sections and brief concluding remarks. The first section highlights the core elements in land registration system and indicates the federal and regional legal framework. The second section reviews the legislative measures in Ethiopia that have introduced land registration with the view to enhance tenure security. Section 3 investigates the fundamental issues which need revision to enhance the role of the land registration system for dispute resolution. Sections 4 and 5 discuss major factors that cause land disputes and the impact of land registration in reducing land disputes in the ANRS. Sections 6 and 7 examine the practical application of the land registration system in ANRS to solve land disputes in the region and the problems thereof.

\section{The Core Elements of Land Registration System and Ethiopia's Legal Framework}

Land registration practices are very ancient activities, and there is a settled meaning attached to the terms. The concept of land registration system includes two related systems, namely, 'cadaster' and 'land register'. ${ }^{2}$ The term 'cadastre' is used mainly in continental Europe (notably in France) where it was originally linked to taxation purposes (fiscal cadastre), as opposed to the Anglo-American legal regimes ${ }^{3}$ where it was introduced to enhance land conveyancing. An authoritative definition of cadastre is given as follows:

\footnotetext{
${ }^{2}$ Other terms often used in the cadastral literature, sometimes interchangeably, include land titling, land certification and formalisation. For a detailed discussion on the meaning of each of these terms, see Melkamu Belachew (2015), "Modelling Legislation for a Sustainable Cadastral System" (unpublished $\mathrm{PhD}$ thesis, the University of Melbourne, Melbourne Law School), pp. 28-29. In this article, the term 'land registration' is used to refer to either cadastre or land register depending on the context in which either is used.

${ }^{3}$ Gerhard Larsson (2000), Land Registration and Cadastral Systems: Tools for Land Information and Management (Meddelande, $2^{\text {nd }}$ ed), p. 24.
} 
A cadastre is normally a parcel based, and up-to-date land information system containing [a] record of interests in land. ... It usually includes a geometric description of land parcels linked to other records describing the nature of the interests, the ownership or control of those interests, and often the value of the parcel and its improvements. It may be established for fiscal purposes (e.g. valuation and equitable taxation), legal purposes (conveyancing), to assist in the management of land and land use (e.g. for planning and other administrative purposes), and enables Sustainable Development and environmental protection. ${ }^{4}$

The term 'land register' (also sometimes referred to as 'land registration') is normally an up-to-date and ownership-based record system. The term is (more or less exclusively) used in the Anglo-American world (traditionally known as the common law world), although the German land registration system (Grundbuch) also refers to the same concept. ${ }^{5}$ Henssen defines land register as "a process of official recording of rights in land through deeds or as title on properties" thereby providing "an official record (land register) of rights on land or of deeds concerning changes in the legal situation of defined units of land" and giving "an answer to the questions who and how". ${ }^{6}$

According to the Federal Rural Land Administration and Use Proclamation (enacted in 2005), "land registration means the process whereby information on the expression of rural land use right and holding is gathered, and analysed". 7 The Urban Landholding Registration Proclamation (enacted in 2014), defines "registration" as the process by which a landholding right, restriction, and responsibility are registered in the legal cadastre register. ${ }^{8}$ And it defines 'legal cadastre' as an updated landholding information system containing a record of the rights, restrictions and

${ }^{4}$ The International Federation of Surveyors (1995), FIG Statement on the Cadastre (Pub. No 11).

5 Jaap Zevenbergen (2002), Systems of Land Registration Aspects and Effects (PhD Thesis, University of Melbourne), p. 27.

${ }^{6}$ Jo Henssen (1995), Basic Principles of the Main Cadastral Systems in the World. In Proceedings of the One Day Seminar held during the Annual Meeting of Commission 7, Cadastre and Rural Land Management, of the International Federation of Surveyors (FIG), May 16, Delft, The Netherlands.

${ }^{7}$ Federal Democratic Republic of Ethiopia Rural Land Administration and Land Use Proclamation, 2005, Proc. No, 456/2005, Fed Neg. Gaz, Year II, No. 44, Art. 2(15).

${ }^{8}$ Federal Democratic Republic of Ethiopia (FDRE) Urban Landholding Registration Proclamation, 2014, No.818/2014, Fed. Neg. Gaz., Year 20, No.25, Art. 2(18). 
responsibilities on a defined legal boundary for each landholding demarcated as parcel on map. ${ }^{9}$

The Amhara Rural Land Administration and Use Proclamation (enacted in 2017) defines 'land registration' as a process of information collection and organization in the rural areas to indicate rural land use right and landholding. ${ }^{10}$ The repealed Revised (Amhara) Rural Land Administration and Use Determination Proclamation No. 133/2006 had a different definition. It defined the term as "an activity of registering the detailed information about location, area, boundaries, fertility grade, and the identity of the holder on the book concerning the rural land" ${ }^{11}$ While the former refers to information about land rights, the latter refers to information about the land, i.e., the land parcel. On the other hand, except the Urban Landholding Registration Proclamation, the other land laws do not mention the word 'cadastre'. Even the former does not use the term 'cadastre' but 'legal cadastre' which, as mentioned earlier, refers to 'land register'.

The confusion on the use of the words 'cadastre' and 'land register' in Ethiopia's land laws results from the lack of clear understanding in the registration system as to which land registration system, i.e. cadastre or land register or both, it aims to apply. Although a separate investigation needs to be made, the land registration system -especially the rural land registration system- seems to apply to (i) the registration of land parcels and (ii) the rights, restrictions and responsibilities. This approach is close to what is known as a multipurpose cadastre where the two systems are functionally and institutionally merged in some countries such as Sweden. ${ }^{12}$

With regard to the scope of registration, the Federal Urban Landholding Registration Proclamation stipulates that all rights, restrictions, and responsibilities stipulated in contracts relating to immovable property shall

\footnotetext{
${ }^{9}$ Id., Art. 2(5).

${ }^{10}$ Amhara National Regional State (ANRS) Revised Rural Land Administration and Use Determination Proclamation, 2012, Proc. No. 252/2017, Zikre Hig, Year 22, No. 14, Art. 2(11).

11 Amhara National Regional State (ANRS) Revised Rural Land Administration and Use Determination Proclamation, 2006, Proc. No. 133/2006, Zikre Hig, Year II, No. 18, Art. 2(20).

${ }^{12}$ Melkamu Belachew (2008), “An Administrative Approach to the Need for Effective Real Estate Registration in Bahir Dar City: A Tool for Safeguarding Dwellers' Real Property Rights" (unpublished MSc Thesis, the Royal Institute of Technology (KTH), Stockholm, Sweden), p. 15.
} 
be registered. ${ }^{13}$ The contracts may be related to "total or partial sale, donation, inheritance, assignment of share, contribution in kind", mortgage, lease, sub-lease, rent, property attachment, and "other act or event" as may be permitted by law. ${ }^{14}$ Moreover, "all decisions, orders rendered or contracts concluded by a legally authorized organ to extinguish, reduce, expand, modify or amend rights, restrictions or responsibilities" shall be registered. ${ }^{15}$ This is true of the Amhara region as it may be inferred from the provisions of Amhara rural land administration and use proclamation. ${ }^{16}$

\section{Overview of Initiatives towards Land Registration Systems}

Land registration systems were given little attention in Ethiopia before the 1990s. Berhanu and Fayera state the practice before 1998 as follows:

In Ethiopia, there has never been a system of systematic rural land registration. During the Imperial regime before 1974, landowners registered the size of all their plots of land, using local units of measurement, to enable tax collection. Land transactions and agreements over land use were generally not registered using written documents, but were confirmed in the presence of witnesses. When land disputes arose, the only evidence presented by claimants was tax receipts. In towns, however, some sort of registration of urban land existed. Land was measured and owners held certificates that certified occupation and ownership, e.g. uses for residential houses, business, etc. The town municipalities were responsible for land registration and administration.

After the land reform of 1974, the newly established lower administrative structures (peasant associations) were given the power of land registration within the boundary of the area for which they were responsible. The land registry listed the names of all peasant association members entitled to user rights over land, an estimation of the area and quality (in local units of measurement), the number of parcels and approximate location of landholdings. Only where land disputes arose, characteristics like boundaries and locations were mentioned in documents (e.g. at local courts). The

\footnotetext{
${ }^{13}$ Federal Urban Landholding Registration Proclamation, supra note 8, Art. 30(1).

${ }^{14}$ Id., Art. 30(2) (4) (5); Federal Rural Land Administration and Land Use Proclamation, supra note 7, Art. 6(5)(6).

${ }^{15}$ Urban Landholding Registration Proclamation, supra note 13, Art. 30(3).

${ }^{16}$ See for example, ANRS Rural Land Proclamation, supra note 10, Art. 34. For a more detailed discussion, see Berihun Adugna Mihret (2007), "Contracts Relating to Rural Land Holding: Form, Registration and its Legal Effect in Amhara Region", ANRS Justice Professionals Training and Legal Research Institute Law Journal, Vol. 2. No.1, pp. 184-195.
} 
Achievements and Gaps in the Application of the Land Registration System in ANRS ... 37

information collected in the registry was used for taxation and during land redistribution activities. The user of the land had no document, except for the tax receipts. ${ }^{17}$

This shows that the registration practice was not systematic, and it did not fully cover a specific land registration area or region. Rather, the registration was carried out with respect to parcels on individual basis when it became necessary for levying land tax. This may not fit into the meaning of land registration per se (to be defined later), and it was merely a temporary identification of a parcel or plot of land for the specific purpose. According to Tarekegn, the basis for the system of registration conducted in urban areas especially in Addis Ababa for a long time was Legal Notice that was operational for many decades although he also indicated that the Municipality applied customary rules as that rule did not meet the needs of land registration. ${ }^{18}$

It needs to be noted that the land administration system in Ethiopia was predominantly informal based on customary practices. Article 3364 of the Ethiopian Civil Code provides that "the customary rules relating to the formalities to be complied with during the transfer or extinction of the ownership of immovable property" shall be applicable until the rules on register of immovable properties are activated. ${ }^{19}$ In practice too, most dealings, land management activities and other activities relating to immovable properties have long been made by municipalities and justice offices without adequate formal system backed by complete land registration legislation. There were, in fact, few sporadic attempts to put in place sound land administration system in a systematic manner. In this regard, the introduction of modern land registration rules in the Ethiopian Civil Code of 1960 under Title X (Articles 1553-1646) that were suspended until their enforcement were "to be fixed by Order published in Negarit Gazeta" ${ }^{20}$ and

${ }^{17}$ Berhanu Adenew and Fayera Abdi (2005), "Land Registration in Amhara Region, Ethiopia" (Research Report 3, Central Research Department of the UK's Department for International Development), pp. 8-9.

${ }^{18}$ Tarekegn Tefera (1990), The Requirement of Registration in the Transfer of Ownership under Contract of Sale (unpublished LLB Thesis, Addis Ababa University, Faculty of Law), pp. 31, 32.

${ }^{19}$ Civil Code of the Empire of Ethiopia Proclamation, 1960, Title X, Proc. No. 165/1960, Neg. Gaz, Extraordinary Issue, No. 2.

${ }^{20}$ See ibid. However, this Title has never come into force because an order setting the date for its application was not issued as per Article 3363(1) of the same law. 
preparation of the Draft Land Registration Proclamation in 1972 can be mentioned. ${ }^{21}$

These realities indicate that public commitment for sound land registration system was inadequate. The need for land registration system was thus long overdue; and some key policy and legislative initiatives are made since 1997 towards establishing sound rural land management and administration system through land registration and certification to enhance tenure security. Setting aside the question whether this certification amounts to land registration per $s e,{ }^{22}$ the initiative has made Ethiopia's land certification system as one of the largest, fastest and least expensive land registration system reforms in Africa. ${ }^{23}$

At national level, the first law on land administration and use is the Federal Government Rural Land Administration that was enacted in July $1997 .{ }^{24}$ In Tigray, the first regional land administration law was adopted ${ }^{25}$ in March 1997 which preceded the adoption of the Federal Proclamation No 89/1997 (by a few months). Later, the ANRS issued the first law on rural land administration in 2000 following the issuance of the Federal proclamation. ${ }^{26}$ ANRS also issued the little known Land Administration and Land Use Policy in the same year. ${ }^{27}$ The State's constitution provides that the region has the power to administer land and natural resources in its domain. ${ }^{28}$ The region established the Environmental Protection, Land Administration and Use Authority under Proclamation No. 47/2000 to enforce the laws and policy. ${ }^{29}$

${ }^{21}$ See Tarekegn, supra note 18, p. 30.

${ }^{22}$ This article does not examine this question. We can consider the system as a variant of land registration system, and the terms are used interchangeably in this article.

${ }^{23}$ Sosina Bezu \& Stein Holden (2014), "Demand for second-stage land certification: Evidence from Household Panel Data", Land Use Policy, vol. 41, p.194 citing Deininger, K. et al (2008), 'Rural Land Certification in Ethiopia: Process, initial impact, and Implications for other African Countries', World Dev., vol 36, no 10.

${ }^{24}$ Federal Democratic Republic of Ethiopia Rural Land Administration Proclamation, 1997, Proc. No. 89/1997, Federal Negarit Gazeta, Year 3, No. 54.

25 Tigray National Regional State's Rural Land Usage Proclamation, 1997, Proc. No. 23/1997, Tigray Neg. Gaz. , Year 16, No.1.

26 The Amhara National Regional Rural Land Administration and Usage Determination Proclamation No. 46/2000.

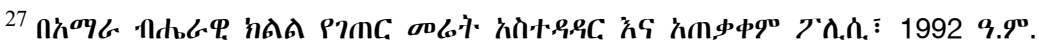

${ }^{28}$ See, for example, The Revised Amhara National Regional Constitution Approval Proclamation, 2001, Proc. No. 59/2001, Zikre Hig, Year 7, No. 2, Art. 47(2.3).

${ }^{29}$ The Regional Environmental Protection, Land Administration and Use Authority Establishment Proclamation No. 47/2000. 
Whether this first generation of legislative measures in land administration had really intended land registration systems is very doubtful as none of the provisions in these laws mentions the term 'land registration' or its equivalent. For example, the first Land Administration Proclamation No. 46/2000 of ANRS merely states that "so long as the land users utilize the land according to the established rules, this proclamation assures and secures their holding and use rights" and that tenure security enables "the peasant to work for sustainable development". ${ }^{30}$ Perhaps, the term "tenure security' may imply land registration; and carrying out land registration on this basis is arguably implied.

Although these first generation land administration laws did not clearly address land registration, the practice of land certification began soon after their adoption. ${ }^{31}$ That means, actually, these laws led, tacitly, to the issuance of a 'Primary Book of Landholding' to the landholders based on their land acquisition through previous land redistribution measures. ${ }^{32}$ The issuance of land certificates began in the region of Tigray in $1998 .{ }^{33}$ Formal land registration started in 2002 in ANRS while Oromia and the Southern Nations Nationalities and Peoples Region followed suit. ${ }^{34}$ In ANRS, land registration started as a pilot program in two pilot woredas, namely, Gozamen in East Gojjam and Dessie Zuria in South Wollo Zone through the conventional form of registration or by using ICT. ${ }^{35}$ Towards the end of 2003, land registration started in all rural woredas of the region, in what is sometimes

${ }^{30}$ The Amhara National Regional Rural Land Administration and Usage Determination Proclamation No. 46/2000, Art. 6(3).

${ }^{31}$ In Amhara region, two proclamations, namely, the ANRS Rural Land Administration and Use Determination Proclamation No. 133/2006 and the Revised Rural Land Administration and Use Determination Proclamation No. 252/2017 were adopted subsequently. The practice of land registration and legislation is improving from time to time in the region. But at federal level, legislation improvement is slow.

32 The Amhara National Region Reallotment of Rural Land Possession Proclamation No 16/ 1996, Zikre Hig, Year 1, No 16.

${ }^{33}$ Felix M. Muchomba (2017), "Women's Land Tenure Security and Household Human Capital: Evidence from Ethiopia's Land Certification”, World Dev., Vol. 98, pp. 310, 313.

${ }^{34}$ Berhanu and Fayera, supra note 17, p.10; Muchomba, supra note 33, p. 313

35 Id., p. 13; Gizachew Abebe, Tigistu Gebremeskel and Rohan Bennett (2015), "Implementation Challenges of the Rural Land Administration System in Ethiopia: Issues for Land Certification and the Information System." (Paper prepared for presentation at the 2015 World Bank Conference on Land and Poverty, Washington DC, March 23-27, 2015), p.14. 
referred to as unconventional or traditional system of land certification. Research shows that a 'Primary Book of Landholding' was issued to almost all landholders in these regions under the first phase of the land certification program. ${ }^{36}$

Currently, there is the process of undertaking the second level certification and the issuance of "Secondary Book of Landholding" which involves extensive surveying, boundary demarcation and potentially the use of ICT technology. The establishment of an efficient land administration system was one of the targets in the first Growth and Transformation Plan $(2010 / 11-2014 / 15){ }^{37}$

Since 2005, second-level pilot land certification process was implemented in Tigray, Amhara, Oromia and Southern Nations, Nationalities, and Peoples' Region (SNNP) from 2005 to 2013. ${ }^{38}$ Concerning the coverage of the second level certificates in Ethiopia, Gizachew et al indicated that $27 \%$ of the surveyed and adjudicated parcels were provided with second level certificates by $2015 .{ }^{39}$ It can be observed that these attempts are meant to introduce and enhance a formal and relatively modern land management system.

${ }^{36}$ Lauren Persha, Adi Greif and Heather Huntington (2017), “Assessing the Impact of Second-Level Land Certification in Ethiopia" (Paper prepared for presentation at the '2017 World Bank Conference on Land and Poverty' The World Bank-Washington DC, March 20-24, 2017), p.5; Muchomba, supra note 33, p.313 (citations omitted). In Ethiopia the land certification has been undertaken in two phases. The first phase is called Primary Book of Holding or $1^{\text {st }}$ level certification that involved the demarcation of parcels and issuance of holding certificates based on customary surveying methods and less modern registration system without maps. The second phase is called Secondary Book of Holding or $2^{\text {nd }}$ level certification that involves more advanced surveying and registration methods and certificates of holding. See Shewakena Aytenfisu Abab (2007), "An Assessment of Rural Land Registration and Land Information System in Amhara Region, Ethiopia: a Land Administration Perspective" (unpublished MSc thesis, the Royal Institute of Technology, Department of Real estate Planning and Land Law, Sweden), pp. 29-31.

${ }^{37}$ Ministry of Finance and Economic Development (MOFED), (2010). The Federal Democratic Republic of Ethiopia Growth and Transformation Plan (GTP) 2010/112014/15, Addis Ababa, Ministry of Finance and Economic Development.

${ }^{38}$ Persha, Greif and Huntington, supra note 36, p.3.

${ }^{39}$ Gizachew, Tigistu and Rohan, supra note 35, p.16. 


\section{Factors towards Sustainable Registration Systems that Reduce Land Disputes}

Although land registration systems are useful in reducing land disputes and conflicts, there are some essential conditions that help to establish them in a sustainable manner. Sustainable land registration system may be established successfully if at least five conditions are fulfilled. ${ }^{40}$ First, there is a need for good government and a sound political environment. Second, institutional capacity is required -an efficient system of institutional machinery is vital to implement or achieve the desired functions of a land registration system. Third, a land registration system needs to be generally based on what landholders already know about their property rights with land; this means, a sustainable land registration system must incorporate customary forms of tenure.

The fourth condition for sustainable registration system relates to the necessity of regular updating to keep it at pace with new circumstances at the level of each proprietor and property object, or even on a larger scale. Updating of the land registration system is as important as or even more important than the initial design of the system. Finally, a sustainable land registration system requires a sound legislative framework designed based on a sound land policy. While land policy gives the general directions of land use, regulation and management, a legislative framework provides a mechanism for delivering all the necessary components, principles, requirements and functions of a sustainable land registration system.

The fulfillment of some of the above essential conditions (at federal and ANRS levels) may easily be evaluated with respect to few selected issues. One essential question is related to the issue of land ownership which is fundamentally a policy matter. Article 40(3) of the FDRE Constitution stipulates the land ownership policy in Ethiopia which states that land is owned by the state and people. ${ }^{41}$ The individuals and legal persons do have

${ }^{40}$ Melkamu, supra note 2, pp.78-104.

${ }^{41}$ Constitution of the Federal Democratic Republic of Ethiopia Proclamation, 1995, Proc. No. 1/1995. Some persons consider the state of ownership of land by the state and the peoples as a form of joint ownership between the state and the people. See Mellese Damtie, "Land ownership and Its Relations to Sustainable Development" in Muradu Abdo (ed), Land Law and Policy in Ethiopia since 1991: Continuities and Changes (Ethiopian Business Law Series, Faculty of Law, Addis Ababa University, 2009), pp. 31-38; Daniel W/Gebriel Ambaye (2013), "Ethiopian Land Law". Institute of Land Administration. Bahir Dar University. However, there can be arguments 
only holding right both in rural and urban areas. The landholding in urban areas is leasehold which may be considered as a special type of holding right. ${ }^{42}$ This policy of public or collective ownership instigates many disputes for several reasons. First, it does not recognize other forms of ownership on land such as individual ownership. Even if the Constitution recognizes full private property right on permanent attachments on land under Article 40(7), it is not clear whether this means private ownership although it may be positively interpreted as private ownership.

In fact, there is wide practice that individuals are prohibited to sell their houses in rural areas as the building is considered, albeit wrongly, to be the same as the land itself on which the building is located. ${ }^{43}$ This creates disputes between individuals and the government relating to the exercise of property rights. Putting everything rigidly under a single type of ownership is also problematic as it opens rooms for abuse of land management power by the government. Second, the division of property right on a similar property or land as ownership right for the government and holding right for the individual provides a fertile ground for disputes during valuation of the property when the property changes hands through different mechanisms. Thus, in the case of expropriation, the government tends to lower compensation. ${ }^{44}$

In this respect, lessons can be drawn from the Chinese land law which allows wider tenure security to landholders even though it considers land as publicly owned under two classifications, i.e. state ownership and collective ownership. Yet it does not deny individual ownership over property such as

against this view if the nature of the rights of joint owners are similar in terms of rights and responsibilities. First, the idea of joint ownership is regulated under Title VIII, Chapter One of the Ethiopian Civil Code which assumes equal share of rights and responsibilities including the transfer of the share to outsiders (Ethiopia, 1960). Such idea is not naturally applicable between the state and the public. Second, even if the law provides that the land belongs both to the state and the people, this merely implies that the state plays the role of administration and regulation of the land on behalf of the peoples according to Article 51(5) and Articles 52(2) (d) \& 89(5) of the FDRE Constitution; while the people directly hold and use the land.

${ }^{42}$ See Melkamu Belachew (2020), "Sale or No Sale? The Law and Practice of Sale of Rural Houses in Ethiopia: the Case of Amhara Region", Land Use Policy Journal (Submitted for publication, unpublished).

43 Id., pp. 20-21.

${ }^{44}$ This is a common problem in urban areas too. The seller may understate the price of sale of a building to evade property tax and other payments to the government directed by the lease law (Article 24(3) of Urban Lands Lease Holding Proclamation No. 721/2011. 
houses, buildings and related structures. The Chinese Property Rights Law begins by defining the basic term, 'property rights', as the exclusive right enjoyed by the person to directly control specific properties including ownership, usufructuary and security right in property rights. ${ }^{45}$ The Law categorizes property ownership into three as State (Public) Ownership, Collective Ownership and Private Ownership. ${ }^{46}$ State Ownership includes all natural resources such as mineral resources, waters, sea areas, forests, mountains, grassland, unclaimed land and beaches, land in urban districts, and such rural land and the land on the outskirt of the city specified by law as belonging to the State. Further, Articles 53 and 54 stipulate that the State organs and "the institutions held by the State" have the right to possess, use and to dispose of the real properties controlled directly by them.

Properties under collective ownership include rural lands including land for building houses, forests, mountains, grasslands, unclaimed land and beaches owned collectively according to law; buildings, production devices, farmland and water power facilities owned collectively; facilities with regard to education, science, culture, health and gymnasium collectively owned; and other properties owned collectively. The rules show that individual ownership embraces mainly houses to which the right of inheritance and other legal rights and interests are attached. A legal person such as enterprises and other entities shall have the right to possess, utilize, obtain benefit from and dispose of its real properties.

More provisions on the scope of the rights of house owners are provided. Article 135 of the Law (2007) states a fundamental principle that a person has the right to the use of land for construction in rural and urban areas who may possess, utilize and obtain profits from such land and construct buildings on it. Further, he has the right to transfer, exchange, donate or mortgage the land, or use it as capital contribution. Such land may be acquired by means of assignment or transfer by auction or invitation to bid and not by sale from others. Article 142 states that the ownership of the building and similar structure built by the person with the right to the use of land for construction shall belong to such person be it individual, collective or even the state. The Law also states that dealing with regard to the land for construction use includes the buildings and related structure on the land and vice versa.

\footnotetext{
${ }^{45}$ Property Rights Law of the People's Republic of China, 2007, Art. 2.

${ }^{46}$ Id., Chapter V.
} 
The other matter is related to legislation on the land registration system. The purpose of legislation is to define property rights clearly, the powers and functions of the enforcement institutions during the process of the land registration including updating, the power of the land dispute resolution bodies and the manner of information exchange between the courts and the land management institutions. Fuller has formulated eight principles of the law which he calls implicit laws of lawmaking that a legal system needs to possess or exhibit as a minimal degree of respect and dignity for those affected by it and which, together, give the law its existence. These are generality of law, promulgation or publicity, prospectivity, clarity, consistency or coherence, possibility, constancy, and congruence between official action and declared rule. ${ }^{47}$ In Ethiopia, land registration system legislation is far from being complete.

Two major weaknesses are worth mentioning. The legislation does not regulate (i) how registration applications are submitted to the land registration offices; and (ii) the form of transaction such as sale, lease, gift, inheritance, land exchange, and mortgage that needs updating. These tasks are conducted customarily rather than based on prescribed rules. These gaps have caused many disputes that are litigated in the courts. In one case still pending in a woreda court, ${ }^{48}$ the plaintiff sued the defendant in order to get back the land which she believes is hers acquired through inheritance now unlawfully possessed by the defendant for long time. The defendant responded that he got the land from another person who, consequently, was made to be a party to the case as a guarantor for the defendant or third party defendant. The defendant argued that he got the land from the guarantor through land to land exchange, but the exchange contract was done orally or traditionally and it was not registered and authenticated. The land registration offices only focus on initial registration and give a blind eye to updating registration.

The federal land administration and use law ${ }^{49}$ does not have any provision on updating. The new Amhara land administration and use proclamation has come up with some important updating rules. ${ }^{50}$ It provides powers and functions to the wereda rural land administration and use office

\footnotetext{
${ }^{47}$ See generally Lon L Fuller (1969), The Morality of Law, Rev. Ed. (New Haven: Yale University Press), pp. 46-91.

${ }^{48}$ Mamey Worke vs. Dessie Chalachew, South Achefer Worea Court, File No. 244576, 2020.

${ }^{49}$ Federal Rural Land Administration and Land Use Proclamation, supra note 7.

${ }^{50}$ ANRS Rural Land Proclamation, supra note 10, Art. 43.
} 
which includes the function of designing a system whereby individuals transfer their holding rights through succession, rent, donation or exchange and updating the information by periodically registering changes and new information. ${ }^{51}$

However, it does not put strict obligations on the registration office to discharge its responsibility of registration and updating. For instance, it provides that "when harm [occurs] on any person due to the fault of the registrar, the government body that committed the fault shall be accountable by both civil and criminal responsibility'. ${ }^{52}$ This provision refers to fault in the process of registration. But most problems occur due to the failure of the registration offices to register an updated landholding. There is also lack of awareness on the part of landholders to submit application for registration of updated landholding. Finally, the legislation should have regulated the manner in which the land registration offices provide landholding information to courts who resolve land disputes, including the power of the court and the conditions by which the court may accept or reject the acquired evidence.

The third key problem that exacerbates land disputes in Ethiopia and ANRS is the existence of separate land management and registration institutions for rural and urban land. The existence of separate institutional and legal framework for rural and urban land has led to the establishment of fragmented institutions for land administration and registration as well as corresponding dispute resolution courts. For instance, in Bahir Dar a separate landholding and registration office is established for rural land in the city within the Bahir Dar City Administration. The urban territory is always expanding and as a result it encloses rural land holdings. This evokes the question as to which land management institution and which land law is going to regulate this newly enclosed rural land.

The urban land administration and the rural land administration offices also compete to receive compensation during expropriation of land. Fitzpatrick articulates that under institutional pluralist relations, state agencies "are more likely to pursue their own interests by pandering to a constituency, increasing tax revenues, or implementing a rent-seeking

${ }^{51}$ Id., Art. 48(5).

${ }^{52}$ Id., Art. 34 (6). 
development agenda". ${ }^{53}$ The landholders also consume much time finding and choosing between the institutions to receive land registration service especially relating to obtaining landholding information to submit to courts. These circumstances would ultimately give birth to disputes between landholders and land management institutions.

\section{Nature and Causes of Land Dispute in ANRS}

Generally, disputes or conflicts are a way of life since every human being always lives together with (or close to) other persons. ${ }^{54}$ According to Wehrmann, land dispute is defined as "a social fact in which at least two parties are involved, the roots of which are different interests over the property rights on land, to manage land, to exclude others from the land, to transfer it and to have the right to compensation". ${ }^{55}$ Land disputes and conflicts have many unwanted consequences. These include decreasing quality of life for parts of a society, slow-down investment, result in the loss of land thereby violating property rights, reduce tax revenue, trigger social and political instability, and in short damage the national economy or wealth. ${ }^{56}$ Therefore, it is essential to use land registration systems efficiently and effectively.

Many types of land disputes frequently happen in ANRS. Based on interviews with 30 land administration committee members selected from 6 woredas of ANRS, Gebeyehu states the following:

The major reasons for conflicts, as reported by committee member respondents, were: inheritance related litigations (25\%), boundary conflict $(21 \%)$, rental contract related conflict $(19 \%)$, easement related conflicts $(11 \%)$, communal lands boundary conflicts $(10 \%)$, informal land sale related conflicts $(9 \%)$ and plant shade related conflicts $(5 \%) .{ }^{57}$

${ }^{53}$ See generally Daniel Fitzpatrick (2006), Evolution and Chaos in Property Rights Systems: The Third World Tragedy of Contested Access, The Yale Law Journal, Vol. 115, p.1041 (citation omitted).

54 Pau M Syagga (2010), Expert Analysis: Land Policy and Dispute Resolution Mechanism (newsletter), p. 3.

${ }^{55}$ Babette Wehrmann (2008), Land Conflicts: A practical guide to dealing with land disputes (GTZ), p. 9.

${ }^{56}$ Id., p. 31.

${ }^{57}$ Gebeyehu Belay Shibeshi (2014), Cadastral Procedure and Spatial Framework for the Development of an Efficient Land Administration System for the Rural Lands of ANRS (Amhara National Regional State) of Ethiopia (PhD thesis at the University of Natural Resources and Life Sciences Vienna, Department of Landscape, Spatial and 
In the case of disputes relating to inheritance, dispute arises among family members of a deceased landholder including the ones that may not have blood relationship with the deceased. ${ }^{58}$ Students living far from their families and descendants living in small towns without dependable means of livelihood are usually parties in land disputes. The other common dispute is boundary dispute. Boundary disputes occur between private individual landholders, between private individuals and the state, between administrative units, and between different villagers (over common land such as grazing land). Encroachments of boundary are very common sources of land disputes. Encroachment occurs when one party takes a portion or whole of the land belonging to another. ${ }^{59}$ Moreover, transaction related disputes are very common. The most common nature of such disputes is the non-fulfillment of formal requirements such as registration and authentication of rental and other transactions on land. ${ }^{60}$ Another type of land dispute occurs during trespass which also arises due to an unlawful use of easements. Trespass is an offence committed by entering another person's land without his/her permission. ${ }^{61}$

One fundamental cause of land tenure disputes relates to settings whereby the statutory laws and the customary laws give the real property/land rights to different persons. For example, in ANRS until the adoption of the new land administration laws, it had been a well-established customary practice that sons and daughters of a deceased person inherit the land of their deceased parent irrespective of their age and amount of landholding. The Civil Code also embodies similar inheritance provisions. Likewise, land use rights were hereditary under the rist landholding system that was prevalent in the region until 1974.

Infrastructure Sciences Institute of Surveying, Remote Sensing and Land Information), p. 40.

58 'Family Member' is defined as any person who permanently lives with the landholder sharing the livelihood of the later and who does not have his own regular income. See, ANRS Rural Land Proclamation, supra note 10, Art. 2(6).

${ }^{59}$ Gertrude Sackey (2010), "Investigating Justice Systems in Land Conflict Resolution: A Case Study of Kinondoni Muncipality, Tanzania”' (unpublished master's thesis, ITC, the Netherlands), p.35.

${ }^{60}$ See generally Melkamu B. Moges \& Alelegn W. Agegnehu (2015), "Issues on the Role of Formal Requirements for Validity of Immovable Transactions in Ethiopia: the Case of Amhara Region", Bahir Dar University Journal of Law, Vo.1 6, No. 1.

${ }^{61}$ The Civil Code, supra note 20, Art. 2053. 
However, the land laws in ANRS give entitlement to 'family members' irrespective of their blood bond to the deceased as against direct descendants, i.e. sons and daughters. Thus, According to Proclamation No. $133 / 2006$, the hierarchy of succession without will (intestate succession) includes minor children, minor family members, children who attained majority and without land, family members who attained majority and without land, children who attained majority and with land, and parents. ${ }^{62}$ However, this order is modified in the new Amhara rural land administration and use proclamation. Here, the order of priority is children, parents and family members. ${ }^{63}$ This change of hierarchical order can solve most of the inheritance disputes as it has become closer to the custom of the people.

According to custom, parents give land rights to their children when the latter are married and form new families. Such latent rights are practically 'owned' or held by a family member but under the formal title of parents. ${ }^{64}$ They include inheritance rights, the rights of women at marriage and divorce, and gift of land before or during marriage to a daughter or son known as macha land. ${ }^{65}$ This kind of land transfer is not recognized under the statutory law which means that the right is devoid of legal protection. Even if the beneficiary of the macha land approaches the woreda land administration office for registration of the right as such, the latter will refuse to do so as the land legislation does not have stipulation to that effect. As a result, the beneficiary of such land has insecure tenure and can easily be dispossessed by another claimant. 'The amount of latent rights outweighs the amount of land, and some will lose out'. ${ }^{66}$

Latent rights can, sometime in the future, be converted to formal title but the transition from latent rights to land title is often a period of intense struggle ${ }^{67}$ This has created tenure insecurity particularly under the post1974 land tenure regime, and perhaps more than ever, under current

${ }^{6}$ See The Rural Land Administration and Use System Implementation Regulation No. 51/2007, Zikre Hig, Council of the Amhara National Regional State, Year 12, No 14, Art. 11(7) and ANRS Rural Land Proclamation, supra note 11, Art 16 (5).

${ }^{63}$ ANRS Rural Land Proclamation, supra note 10, Art 17(5).

${ }^{64}$ Svein Ege (2017), "Land Tenure Insecurity in Post-Certification Amhara, Ethiopia", Land Use Policy, p.4.

${ }^{65}$ Id., p. 8.

${ }^{66}$ Allan Hoben (1973), Land Tenure among the Amhara of Ethiopia: The Dynamics of Cognatic Descent (Chicago and London, University of Chicago Press) cited in Svein, supra note 62, p. 8.

${ }^{67}$ Svein Ege, supra note 64, p. 8. 
conditions. ${ }^{68}$ In one case presented to the Bure Woreda Court, ${ }^{69}$ the plaintiff sued the defendants (her father and uncle) and requested that they surrender land, 5.75 Gezim [1.4 ha], to her on the ground that she was the only family member of the deceased (her grandmother and mother of the defendants) thereby having priority of inheritance according to the land law active at the time. $^{70}$ The defendant (her uncle) argued that the land lawfully belongs to him, among other things, because he is the direct descendant of the deceased having priority to the plaintiff, a grand-daughter of the deceased. The woreda court decided on behalf of the plaintiff considering, according to the applicable law, that she is a family member of the deceased and the High Court confirmed the decision. The judgments of these courts were later reversed on the ground of 'res judicata' without going into the merits of the matter. $^{71}$

In another case, presented to the Debub Achefer Woreda Court, ${ }^{72}$ the plaintiff sued the defendant, her father, stating that he has possessed the land that belonged to her deceased mother and which she argued needs to be transferred to her by inheritance. Another party intervened in the case arguing that the land belongs to neither of the parties in the case but to him as it was transferred to him as macha land through an informal, customary agreement between the deceased woman and the defendant. The court rejected the latter's claim stating that the marriage land or macha land was not transferred to him fulfilling formal requirements of registration or authentication. The case was appealed to the High Court which reversed the decision of the lower court and remanded it to the latter. ${ }^{73}$ The lower court then modified its decision in favor of the intervening party on the ground that the non-registration was caused by the failure of the land registration office to register the land on the ground that the land was below the minimum size put for registration. Another root cause of land dispute relates

${ }^{68}$ Ibid.

${ }^{69}$ Child Meretu Yenegeta v Gelaye Mekonnen \& Yenegeta Mekonnen, Bure Wereda Court, File No 1034, 2010.

${ }^{70}$ See ANRS Rural Land Proclamation, supra note 11, Art. 16(5) and ANRS Rural Land Regulation, supra note 62, Art. 11(7).

${ }^{71}$ Gelaye Mekonnen v Child Meretu Yenegeta, ANRS Supreme Court Cassation Bench, File No 10800, 2012.

${ }^{72}$ Wubalem Getie v Abuhay Getie Teshager, Debub Achefer Woreda Court, File No 23876, 2019.

${ }^{73}$ Bihonegn Getie v Abuhay Getie Teshager et al, Bahir Dar and Its Surroundings High Court, File No 0320758, 2019. 
to population increase. In ANRS, the population is rapidly increasing thereby resulting in high demand to farmland and severe land fragmentation.

Moreover, disputes are caused by the failure to pay compensation during expropriation. There are many cases of failure to pay compensation during an expropriation action which may, inter alia, be reflected in delay in payment, low compensation, and non-payment. In one case, the plaintiff sued the defendant in 2005 before the West Gojjam Zone High Court in order to get fair compensation on her land (about 2 ha) expropriated by government in $2003 .^{74}$ The case was closed in November 2010 after more than five years of protracted judicial argument. The plaintiff lost the case. The decision of the High Court was not altered in the ANRS Supreme Court on appeal. ${ }^{75}$

Maladministration is another cause of land conflicts in the region. Maladministration occurs where land institutions do not play their roles such as poor record keeping, posing unnecessary bureaucracy, and allocating land in such a manner that it creates overlapping interests. As we shall see later, corruption which is a sign of maladministration ${ }^{76}$ is a rampant problem of land administration in ANRS. As Wehrmann observes, "dysfunctional institutions only act as catalysts for land conflicts-selfish individual interests being the deeper causes". ${ }^{77}$

\section{The Role of the Land Registration System in Reducing Land Disputes}

One of the objectives of the current rural land registration system is to create conducive environment to resolve land dispute amicably and efficiently. Land certification is also a good measure to reduce land disputes and enhance tenure security among land holders and users by clarifying land rights and beneficiaries of the rights. One of the results which was hoped to be achieved during the initial stage of the land registration in Ethiopia was a significant reduction of land disputes. ${ }^{78}$

${ }^{74}$ Emahoy Guale Guade v Ministry of Defence, Western Gojjam Zone High Court, File No 09768, 2010.

${ }^{75}$ Emahoy Guale Guade v Ministry of Defence, ANRS Supreme Court Cassation Bench, File No 15230, 2011.

${ }^{76}$ UN- Food and Agricultural Organisation (2007), Good Governance in Land Tenure and Administration (FAO), pp. 15-17 cited in Melkamu, supra note 2, 73.

${ }^{77}$ Wehrmann, supra note 55, 24.

78 Zerfu Hailu (2016), Land Governance Assessment Framework Implementation in Ethiopia, Final Country Report Supported by the World Bank, p.40. 
This is not to say that conflicts would not arise in the process of registration itself especially in the initial stage of registration. According to Berhanu and Fayera, the process of land registration in ANRS has generated conflict due to land expansions into common lands, illegal occupation, illegal land sales, and confusion on the mandated body for land administration. ${ }^{79}$ It is to be noted that land registration system alone (in its narrow context) may not achieve its objective of reducing land disputes. Kanji et al observed:

In discussing the ability of land registration to help reduce land disputes, registration processes cannot be considered in isolation - they must be placed in a broader context, both in terms of social and political relations (nature of the main types of land disputes in the area, etc.) and in relation to the legal system (dispute settlement institutions, etc.). ${ }^{80}$

Zerfu states that the amount of land dispute relating to rural land is wider than what was anticipated during the launching of the land registration system:

... [I]n spite of all the impressive gains of the land registration and certification activities in Ethiopia, the number of land disputes among landholders and family members is increasing at an alarming rate. It is not strange now to see courts in many parts of the country being congested with land-related cases and farmers filling their halls. For instance, it is reported that land related disputes are claiming more than 70 percent of civil litigations ... and 48 percent of homicide crimes in the Amhara Region Courts ... Although the magnitude is different, the trend is similar in the other regions. ${ }^{81}$

While land dispute during the early stage of land registration is quite normal, land registration generally results in reduced land disputes and better management of the disputes. Studies conducted in Tigray and Amhara regions of Ethiopia showed that land related disputes decreased during and after the land registration and certification. ${ }^{82}$ For instance, in Tigray regional state $66 \%$ of the respondents reported that land related disputes decreased

${ }^{79}$ Berhanu and Fayera, supra note 17, p. 24.

${ }^{80}$ Kanji et al, supra note 1, p.22.

${ }^{81}$ Zerfu, supra note 78, p.40.

${ }^{82}$ See Holden, S.T. \& and Tefera, T. (2008) From Being Property of Men to Becoming Equal Owners? Early Impacts of Land Registration and Certification on Women in Southern Ethiopia (Unpublished Report for UN-HABITAT) cited in Muchomba, supra note 33, p. 314. 
after certification. ${ }^{83}$ Similarly, a case study in ANRS indicates that in areas where land registration and certification takes place, the number of court cases have reduced significantly from 20 to 2 per week. ${ }^{84}$ Another study conducted by Assefa in Fagitalekoma Woreda, ANRS, shows the same result. In that study, the majority out of a total of 100 respondents $(66 \%)$ confirmed that they did not face land related dispute after land registration and certification, while 33\% reported they are affected by land related disputes even after the land registration. ${ }^{85}$

\section{Application of Land Registration System Information for Dispute Resolution in ANRS}

\subsection{Dispute resolution bodies}

Judicial dispute resolution is the most applied land dispute settlement tool in ANRS. In the study area, several courts are established to resolve land and other kinds of disputes. These are the woreda /first instance courts, the high courts and the ANRS Supreme Court. ${ }^{86}$ In ANRS, the land law gives priority to the resolution of disputes at local level with the assistance of the land administration institutional apparatus before resort to courts. ${ }^{87}$ Legislative support to alternative dispute resolution mechanisms, customary mechanisms and administrative remedies are indeed significant. Alternative dispute resolution method is a "term generally used to refer to informal dispute resolution processes in which parties meet with a professional third party who helps them to resolve their dispute in a way that is less formal and often more consensual than is done in the courts". 88

Proclamation No. 252/2017 provides that any land dispute resolution must be first handled between the parties themselves and by the use of

${ }^{83}$ Deininger, et al (2007), Impacts of Land Certification on Land-Related Conflicts in Tigray Region, Ethiopia cited in Assefa Belay (2010), The Effects of Rural Land Certification in Securing Land Rights: A Case of Amhara Region, Ethiopia (unpublished Master's thesis, Geo-Information Science and Earth Observation, ITC, the Netherlands), p. 48.

${ }^{84}$ Deininger et al, (2009), Impacts of Land Certification on Tenure Security, Investment, and Land Markets: Evidence from Ethiopia, p. 9.

${ }^{85}$ Assefa, supra note 83, p.48.

${ }^{86}$ See The Amhara National Regional State Courts' Establishment (re-amendment) Proclamation No 169/2002, Zikre Hig, $15^{\text {th }}$ Year, No. 5.

${ }^{87}$ Zerfu, supra note $78, \mathrm{p} .40$.

${ }^{88}$ Brad Sprangler (2003), 'Alternative Dispute Resolution (ADR)' Beyond Intractability. Eds. Guy Burgess and Heidi Burgess. Conflict Information Consortium, University of Colorado, Boulder. 
arbitrators before the case is submitted to judicial settlement. ${ }^{89}$ Therefore, if an individual takes a case to court without getting the decision of an ad-hoc arbitration body, the case will be rejected by the registrar of the court. But with regard to an administrative decision given by woreda rural land administration and use offices (in relation to measuring land, administering land and other related issues), the aggrieved party may file suit directly to the wereda court within 30 days. ${ }^{90}$ Respondents were asked about their opinion on the importance (or otherwise) of alternative dispute resolution methods and administrative methods. Out of 34 respondents, $88.2 \%$ of the respondents are of the opinion that non-judicial dispute settlement methods should be applied in ANRS while only $11.8 \%$ believe otherwise on the ground that non-judicial mechanisms do not provide a conclusive solution and rather delay the solution.

\subsection{The role of the land registration system in judicial decisions}

Courts in ANRS resolve land disputes in almost all of their decisions based on the cadastral information they receive from the land administration and use offices that are submitted to them upon court order. According to the focus group discussion with the respondents, the types of land information commonly kept under the existing rural land administration system are the area of each land parcel, the adjacent land parcels to a land parcel in the East, West, North and South directions, full name and age of the holder (both husband and wife), degree of soil fertility, the manner of acquisition of the land, the location of the parcel, use of the land, and the land holder's family members accompanied by their age. According to the common practice, ${ }^{91}$ if land is registered in someone's name and if the land registration office proves this in an unchallenged manner, that party has conclusive evidence of his valid landholding right to the land. ${ }^{92}$

${ }^{89}$ See ANRS Rural Land Proclamation, supra note 10, Art 52(1).

${ }^{90}$ Id., Art. 52(6).

${ }^{91}$ However, in rare cases the courts may hold the opposite position that registration does not affect validity. See for example, Berihun, supra note 16, pp.197-204.

92 But we should also note that an immovable transaction although registered may be rebutted in certain circumstances especially following the FSCCD's landmark ruling that land registration evidence given by a land registration office is not a conclusive evidence and may be rebutted by other evidence. See Tilahun Gobeze v Mekete Hailu et al, Federal Supreme Court Cassation Bench, File No. 69821, 2012. In another case, the court decided in favour of the appellant when it held that registration of a gift contract alone does not cure the other defects in the contract. The court saw that the contract does not fulfill the requirements under Art 881 cum. Art 2443 of the 
In other words, the courts decide in favour of a party who has presented an unchallenged evidence of registration in the land registration institutions with respect to both urban and rural lands. ${ }^{93}$ Thus, registration determines validity of the transaction which is the initial cause of transfer of landholding title. This is in clear contradiction with the law which provides that ' $[\mathrm{u}]$ nless any activity concerned with the right and obligations related to land is submitted and registered in woreda branch office of the Authority, it may not be an objection to the third parties' ${ }^{94}$ This rule implies that registration has nothing to do with the validity of the immovable transaction as between the parties to the transaction. ${ }^{95}$

The following review of some cases indicate how courts apply the land registration information in their attempt to solve land disputes. ${ }^{96}$ In Ibrahim Muhamud et al v. Deboch Zewdie, ${ }^{97}$ the petitioners lodged an appeal against the decisions of the lower courts. The argument of the defendant in his original pleading was that the petitioners had unlawfully taken his land and planted eucalyptus tree. The petitioners denied the allegation. The appellate court confirmed the decision of the lower courts which ruled in favour of the defendant based on a title certificate (presented by the defendant) issued by the land register institution. In Tiblet Tesfa v. Abuhay Tadese case, ${ }^{98}$ the appellant required the return of the full rental money as the defendant failed to cause the registration of the rental contract. The court held that the defendant has to return the rental money paid equivalent to the one year period in which the appellant held the land out of the total rental period of 25 years. This means the court ruled that the rental contract was invalid due to failure of registration.

Ethiopian Civil Code, namely, that it was not read in the presence of the testator and of four witnesses. See Abate Kassa v Teshale Kefale, ANRS Supreme Court Cassation Bench, File No. 24918.

93 This is, in fact, in line with ANRS Rural Land Proclamation which provides that " "[t]he person who is granted the land holding certificate in his name shall, unless a contradictory written document is submitted, be considered legal holder of the land". ANRS Rural Land Proclamation, supra note 10, Art 24(4). Similar provisions are stipulated under Articles 1195 and 1196 of the Ethiopian Civil Code.

94 Id., Art. 23(4) 'emphasis added'.

${ }^{95}$ See Berihun, supra note 16, pp.200-201. For an elaborated discussion and argument, see generally Melkamu \& Alelegn, supra note 60.

96 Most of these cases were first reviewed in Melkamu \& Alelegn, supra note 60, Section 4.3.

${ }^{97}$ Ibrahim Muhammed v Deboch Zewde et al, ANRS Supreme Court Cassation Bench, 23764, 2013.

98 Tiblet Tesfu v Abuhay Taddesse, ANRS Supreme Court, File No. 34089, 2013. 
Achievements and Gaps in the Application of the Land Registration System in ANRS ... 55

In Lema Tekle v. Kinfe Adisu, ${ }^{99}$ the petitioner requested the reversal of the decision of the lower courts which held that the petitioner must return the land to the defendant which he held through rent. The Supreme Court held that petitioner must return the land to the defendant because the rental contract he relied on was not registered in the land register institution. In the Yezanu Motbaynor v. Heirs of Getachew Abate, ${ }^{100}$ the appellant requested that the defendants must return the lands they held to her as she is the lawful heir of a deceased woman due to her being a family member. The defendant argued that he got the lands through donation/gift contract allegedly registered in the land register institution. The ANRS Supreme Court held that defendant's claim is not tenable because there was no evidence to show that the donation contract was registered and that the donation contract did not embody the signature of the 'donor'.

In Asrat Mekonen and Banchayehu Asres v. Kinde Abera and Yektie Tarko, ${ }^{101}$ the appellants requested that the rental contract be cancelled because the defendants failed to discharge their obligation of paying the rent in kind (share-cropping). The defendants argued that they rented the land for 25 years and hence should not return the land before the expiry of the rental period. The court held that the rental contract cannot be invalidated as it was registered in the land register and hence the defendants may not return the land. In Mosit Anteneh vs. Checkol Alemu case, ${ }^{102}$ the appeal was against the decision of the lower High court which ruled that the appellant must return to the defendant the land the appellant's deceased husband allegedly took through rent. The ANRS Supreme Court reversed the decision and held that appellant shall not return the land to the defendant because the evidence from the land register institution showed that the land was registered in the name of the appellant's deceased husband during the first registration process and then transferred to the appellant.

The overview of the court cases highlighted above shows the role of the land registration system information for the settlement of land disputes in the courts of ANRS. Evidence submitted to a court may assume two forms. First, evidence may be submitted as an attachment to a pleading. This

${ }^{99}$ Lema Tekle v Kinfe Addisu, ANRS Supreme Court Cassation Bench, File No.23770, 2013.

100 Yizanu Motbaynor v Heirs of Getachew Abate, ANRS Supreme Court, File No. 33427, 2013.

101 Asrat Mekonnen et al ( 2 persons) v Asres Kinde et al (2 persons), ANRS Supreme Court, File No. 33666, 2013.

102 Mosit Anteneh v Chekol Alemu, ANRS Supreme Court, File No. 32993, 2012. 
attachment is a certified copy of a title certificate or land registration book issued by the woreda rural land administration and use office. The second option is a letter written by a land register institution -in response to court order- to provide the required information which verifies that the person in whose name the land in dispute is registered. The latter is used when the party has for some reason failed to attach the title certificate.

\section{Problems in the Application of the Land Registration Information by the Courts}

As we discussed above, an appropriate land registration system helps reduce land disputes (preventive measure), and facilitates land dispute resolution (curative measure). Conversely, a sheer lack of land registration system can cause land disputes. On the question of the usefulness (or otherwise) of the land information/evidence supplied by land offices upon request by the courts, the majority of the 11 respondent judges $(91.2 \%)$ stated that the land registration information is useful, and only $8.8 \%$ of them responded in the opposite. Even the latter have not totally disregarded the usefulness of the new land registration system. They stated that before the information is used, it has to be properly and comprehensively processed and recorded (perhaps to refer to the need to introduce the Secondary Book of Land Holding).

Thus, there is clear understanding of the benefits and role of a sound land registration system. Moreover, the respondent judges have responded to the question regarding the relative quality and type of evidence presented to the courts to settle land disputes comparing (i) the pre and post-2002 period, and (ii) the period since the land registration and certification system was put in place in ANRS. 90.9\% of the respondents observed that, with all its defects, the land administration and land registration system has made the post-2002 period highly useful in terms of, among other things, contributing to the settlement of disputes over rural land through provision of land use information.

Although the level of land related disputes is generally decreasing through time after the land registration system started in the region, there is clearly a lot more work to be done. ${ }^{103}$ The positive results obtained must be

103 The National Land Policy of Kenya suggests the following principles to reduce land disputes: establish independent, accountable and democratic system backed by law; establish appropriate institutions for dispute resolution and access to justice within communities with clear operational procedures; include community members in decision-making and record keeping to ensure transparency and the development of 
seen in light of the land administration system (prior to land registration and certification) where the role of government was insignificant and the landholders had to only rely on their own customary ways of land dispute resolution without state supervision.

Indeed, the data obtained from the judges and land administration and use staff (working in the study area) clearly show that the effort of land conflict resolution is highly challenged by the defects of the new land registration system. Twenty three woreda land administration and use staff were asked to identify the problems in relation to their efforts to give documentary evidence to courts to help resolve land disputes. In their responses, the majority of the respondents (95.7\%) stated the lack of a complete land registration system as the key problem. In this connection, problems related to collecting information in different rural areas (transport, per diem, misinformation, etc.) were raised by $69.6 \%$ of the respondents. Land administration and use offices should be fully cognizant of their duty to keep complete and up-to-date land information.

Because the land registration system information about landholder and landholding is incomplete, the woreda land administration and use offices are forced to go to fields to get the required information while they are expected to provide the information by looking at the data kept in their offices. By going to fields as per court orders relating disputes, they take long time to provide information which contributes to the delay of justice and poor quality of decisions of the courts. In fact, some of the problems are beyond the capacity of the land administration and use offices. This is because the registration systems do not entail the recording of plot boundaries in the register, ${ }^{104}$ and this is a major shortcoming of the land registration model in Ethiopia. ${ }^{105}$ Other problems include ethical problems such as corruption $(52.2 \%)$ and gaps in the clarity of the court orders $(52.2 \%)$.

The answer given by 11 judges to the same question is not much different. According to the majority of judge respondents $(81.8 \%)$, the lack of complete land information is the most frequent cause of failure to get adequate evidence to settle disputes. For example, the land registration is not updated and the property rights are not clearly and completely governed in

guiding rules for making decisions on specific matters; and encourage and facilitate the use of alternative dispute resolution mechanisms. Syagga, supra note 54, p. 3.

${ }^{104}$ Kanji et al, supra note 1, p.22

105 Ibid. 
the legislation. Ethical problem mainly corruption ${ }^{106}$ ranks second out of the total of four problems, $72.7 \%$ of the responding judges considering it as such. Lack of proper understanding of the land rules and lack of coordination between the courts and the land offices are both in the third rank $(45.5 \%)$ as factors that hamper adequate evidence to settle land disputes.

This author's observations further relate to one additional central problem faced by courts and land administration and use staff while using the land registration system to resolve disputes. This is related with their level of understanding in the implementation of the land administration and registration laws. In order to identify the person in whose favor the land in dispute is registered, courts usually issue an order for the woreda rural land administration and use office requiring the latter to investigate the true landholder and state this in writing to the court on a specified date. The courts do this even if the party to the case has presented a copy of the landholding certificate.

In their orders, the courts do not even request to know the reason why a given landholding certificate can be acceptable or not. Members of the woreda rural land administration and use office staff go to the place where the parcel in dispute is located and approach a group of people gathered usually in a church. Some individuals in the gathering may raise their hands and tell what they know regarding the landholder. There is a wide room for misinformation and manipulation in this process as a more powerful party would usually prepare individuals who provide wrong information in his favour.

The land administration and use staff has no means of ascertaining whether the information so provided is correct. Even worse, a staff member can be exposed to corrupt practices. It is common to get contradictory information from the registry. In Mamey Workie vs. Chalachew Dessie, the registry first provided evidence saying that the land in dispute originally belongs to the plaintiff but on another round it gave different information that the land belongs to another party, the third party defendant. ${ }^{107}$ The courts receive such information and decide that the land is registered in the name of a party in whose favour the letter is written.

\footnotetext{
${ }^{106}$ It can be seen that the land administration and use staff and judges weigh corruption differently. The former give it lesser weight whereas the latter give it greater weight. The land experts did not want to disclose the existence of corruption on their part while the judges were freer to disclose the problem.

${ }^{107}$ Mamey Worke v. Dessie Chalachew, South Achefer Worea Court, File No. 244576, 2020 .
} 
This practice shows that the certificate of landholding issued by the land administration and use office is actually given little or no role. This means that the letter prepared based on the field report is considered as land registration information and used by courts as conclusive evidence for landholding. Unfortunately, the Revised Rural Land Administration and Use Determination Proclamation No. 252/2017 legalizes this wrong procedure. Article 37(1) of the Proclamation stipulates that "the process of assuring the rural landholding is implemented between the pertinent landholder residing in the kebele or sub-kebele and a pertinent land administration and use committee" by getting [comments from] the people. ${ }^{108}$ In addition to evidence submitted to them in this manner, the courts hear witnesses of either party to the case. However, in practice, courts mainly consider the documentary evidence or letter from the land administration and use offices.

This problem is exacerbated by lack of clarity of the land law on the effect of land holding certificate. In this regard, Proclamation No.133/2006 stipulates that ' $[t]$ he holding certification is a legal certificate of the holder'. ${ }^{109}$ The Amharic version states that the landholding certificate is an evidence of the legally protected right of the landholder. The courts could have applied this provision to apply the correct approach by taking the copy of landholding certificate as evidence of land title which is presented to it by the party or a copy produced from the woreda rural land administration and use office.

Proclamation No 252/2017 has come up with more detailed rules to fill the legal gap in this regard. In addition to stating that the landholding certificate is evidence of the right of the landholder, it stipulates that "[j]udges may not consider any documentary evidence or any witness before consulting the landholding certificate while there is a certificate." ${ }^{110}$ But in practice, various courts have not yet considered this provision in their decisions. Therefore, the courts must give due credit to the land registration system created by the relevant laws, and they should take the information indicated in the landholding certificate as true instead of requiring field reports of the woreda rural land administration and use offices. In other words, the land registration system should not be undermined, and it should be used commensurate with its objectives, i.e., the enhancement of tenure security and proper dispute settlement.

\footnotetext{
${ }^{108}$ ANRS Rural Land Proclamation, supra note 10.

${ }^{109}$ ANRS Rural Land Proclamation, supra note 11, Art. 24(1).

${ }^{110}$ Id., Art. 35(2).
} 


\section{Conclusion}

Generally, the land registration system in ANRS has positive results in reducing land disputes. The courts and land administration offices generally use the land registration system that enhances tenure security and dispute management. Moreover, courts use field reports of land registration information from land administration offices. However, the land registration system in the region is not used (in the settlement of land disputes) to its optimal level of effectiveness and utility. A major setback in this regard is the inadequate attention of the courts to the purpose and essence of the land registration system and its decisive role in determining the rights of landholders. The land registration system should be used in such a manner that it enhances tenure security and proper dispute settlement. Courts should thus rectify their inadequate attention to the information in the landholding certificate as prima facie evidence and refrain from requiring field reports of the woreda rural land administration and use offices.

This is exacerbated by the level of competence of land administration offices in the task of land registration. The other challenge is that the land registration system is not complete as updating of regular transactions is not taking place. Moreover, the list of recognized registrable property rights, restrictions and responsibilities are not fully addressed in legislation. There is thus the need for a strong institutional and regulatory mechanism of land management in ANRS. This has to be implemented with regard to the land administration and use offices at various levels, the court system, and customary dispute settlement mechanisms. Some of the important measures that need to be taken in this regard are sustained public awareness creation on the land administration and information system, establishing a comprehensive and sound land information in an integrated organizational and regulatory structure at all levels that can also be updated easily, facilitating coordination for land information, training and capacity building, and adopting clear procedures (to be used by the woreda rural land administration and use offices) in the delivery of land registration information to courts. 